\title{
ABUNDANCE PATTERNS OF THE WESTERN FLOWER THRIPS, Frankliniella occidentalis (PERGANDE)(THYSANOPTERA: THRIPIDAE), AND ITS PREDATORY BUGS, Orius spp. (HEMIPTERA: ANTHOCORIDAE), ON FABA BEAN IN ÇUKUROVA REGION OF TURKEY
}

\section{Ekrem Atakan}

Plant Protection Department Faculty of Agriculture University of Çukurova Sarıçam, Adana, Turkey

Received - March 04, 2018; Revision - May 15, 2018; Accepted - June 16, 2018

Available Online - June 20, 2018

DOI: http://dx.doi.org/10.18006/2018.6(3).550.562

KEYWORDS
Abundance
Thrips
Predatory insect
Faba bean
Turkey

\begin{abstract}
Thrips species on faba bean cultivated in Adana Province, Turkey, were investigated to determine their natural insect enemies in the 2010-2011,2014-2015, and 2016-2017 growing seasons. Ten thrips species (one species belonging to Aeolothripidae and nine to family Thripidae) were found. The western flower thrips, Frankliniella occidentalis (Pergande) (Thysanoptera: Thripidae), was the dominant thrips species, comprising about $44.4 \%$ of the total samples. Among the natural enemies, Orius niger (Wolff), Campylomma nicolasi Puton and Reuter, and Orius laevigatus (Fieber) were the most notable species. The population densities of thrips and their natural enemies were highest in March. Mean densities of $F$. occidentalis were less than 5 individuals on most sampling dates in experimental fields in which no pesticides were used, but were more than 15 individuals per plant in some sampling months in commercial fields where Orius numbers were relatively lower. Densities of Orius spp. were closely associated with the densities of $F$. occidentalis. Thrips to Orius spp. ratios were less than $5: 1$, indicating that pestiferous thrips might have been suppressed by Orius.
\end{abstract}

* Corresponding author

E-mail: eatakan@mail.cu.edu.tr (Prof. Dr. EkremAtakan)

Peer review under responsibility of Journal of Experimental Biology and Agricultural Sciences.

Production and Hosting by Horizon Publisher India [HPI] (http://www.horizonpublisherindia.in/).

All rights reserved.
All the article published by Journal of Experimental Biology and Agricultural Sciences is licensed under a Creative Commons Attribution-NonCommercial 4.0 International License Based on a work at www.jebas.org.

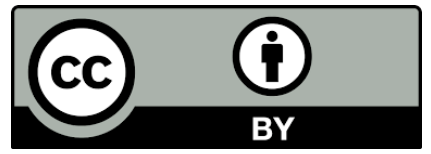




\section{Introduction}

Faba bean (Vicia faba L., family Fabaceae) is a nutritious human food crop containing high protein (Anonymous, 2001). It is widely grown in the eastern Mediterranean region of Turkey where it enriches soil fertility by keeping nitrogen in the soil. Faba bean production is fourth among the leguminous crops grown in Turkey. Atakan (2012) studied the common insect species on faba bean and suggested that leafhoppers (Empoasca spp.) and aphids (Aphis fabae Koch) were the most common species in Turkey. The seasonal densities of the western flower thrips, Frankliniella occidentalis (Pergande), and its generalist predator Orius niger (Wolff) (Hemiptera: Anthocoridae) on faba bean have been studied by Atakan (2010). Frankliniella occidentalis and $O$. niger were the most abundant insect species of faba bean and of weedy plant species (Atakan, 2010). Nuessly et al. (2004) reported 61 herbivorous insect pest species and 32 predator and parasitoid species on faba bean in Florida (USA); and Aphis craccivora Koch (Hemiptera: Aphididae) was the most damaging pest of faba bean in their study.

Cultural and biological control of pest thrips are important elements of integrated pest management strategies in diverse crop plants (Razavi \& Ahmadi, 2016). The use of chemical insecticides against pest insects can cause significant problems to health and environment. Therefore, alternative pest management tactics, such as biological control of pest thrips by generalist predators (e.g., Orius species), are needed (Riudavets, 1995).

Orius spp. were found on various vegetable crops in different parts of Turkey (Bulut \& Göçmen, 2000). They are important biological control agents for suppressing populations of pest thrips, especially the western flower thrips (van de Veire \& Degheele, 1992; Tavella et al., 2000). Orius niger can reduce population pressure of Frankliniella flower thrips in untreated cotton fields in the Çukurova region of Turkey (Atakan, 2006; Atakan \& Gençer, 2008). However the role of Orius spp. as predators of thrips on winter crops, such as faba bean, has not been studied in Turkey.

In Turkey, Faba bean typically is cultivated as a winter crop, with flowering during early winter and spring having various ecological impacts on the population dynamics of $F$. occidentalis and Orius spp. The interaction between F. occidentalis and Orius spp. might help in understanding the predation potential of Orius species on pestiferous insects on arable crops in the region.

Although some associations between pest thrips and generalist predators on faba bean flowers have been studied in restricted areas, the fauna of thrips and beneficial insects and the pest status of thrips, such as $F$. occidentalis in commercial fields of faba beans are not well understood. Additionally, an understanding of plant part preferences of thrips and Orius spp. throughout the season is rudimentary. This information is needed to estimate the densities of both insects. The main objectives of this study were to (i) determine the thrips species and their natural enemies in the Mediterranean region of Turkey, (ii) determine the abundance patterns of F. occidentalis and Orius spp. on faba bean and (iii) determine the choice of faba bean plant parts by $F$. occidentalis and Orius spp.

\section{Materials and Methods}

\subsection{Samplings in experimental plots}

Seasonal abundance of the western flower thrips and its predatory bugs was studied in untreated faba bean plots $\left(500 \mathrm{~m}^{2}, 20 \mathrm{~m} \times 25\right.$ m) at weekly intervals in the Research and Implementation Area of Department of Plant Protection, Faculty of Agriculture, University of Çukurova, Balcall, Adana, Turkey. Sampling was carried out during 10 January-27 March 2010 (12 sampling dates) and 12 January-8 March 2011 (9 sampling dates). The main plot was divided into four sub-plots (each $125 \mathrm{~m}^{2}, 5 \mathrm{~m} \times 25 \mathrm{~m}$ ). Five plants from each sub-plot were randomly selected. Beating of plants to sample thrips species and their predatory insects are commonly used sampling methods (Atakan, 2010, Atakan, 2012). Thus, selected plants were bent down and vigorously shaken in a white plastic container for 5 seconds. Thrips and predators were collected with a fine brush and stored in $2 \mathrm{ml}$ plastic vials containing $60 \%$ ethanol.

When plants were at the flowering stage, five plants from each sub-plot were selected randomly, and 6 leaflets and flowers from each selected plant were sampled for $F$. occidentalis and Orius spp. Leaflet and flower samples from each plant were transferred to the laboratory. To estimate the populations of thrips and beneficial insects including Orius spp., flowers and leaf samples were kept for one or two hours in a deep-freezer and then tapped onto a white plastic sheet. Thrips and predators were collected with a fine brush and kept in $2 \mathrm{ml}$ plastic tubes containing $60 \%$ ethanol for subsequent identification. The same procedure was repeated the next year.

\subsection{Samplings in commercial fields}

Abundances of $F$. occidentalis and Orius spp. were investigated in commercial faba bean fields during the 2014-2015, and 20162017 growing seasons in Adana Province, Turkey. Surveys were carried out once per month during the growing season. During surveys, the same fields were regularly sampled. In each survey, 4-8 fields were visited to determine the numbers of thrips and predatory insects. The size of commercial fields sampled varied from 0.5 to 1.0 ha. Sampling was carried out when plants were flowering. Each field was divided into four quarters (1.250-2.500 
$\mathrm{m}^{2}$ sub-plots) as replicates. Five plants in each sub-plot were randomly selected. Under laboratory conditions, the thrips samples were placed in vials containing AGA solution (10 parts $60 \%$ ethanol, 1 part glacial acetic acid, and 1 part glycerine) and kept for subsequent identification.

\subsection{Identification of insects}

Slide-mounted thrips (adults) were identified by using the keys given by zur Strassen (2003) and Balou et al. (2012). Orius spp. were identified with the keys given by Önder (1982) and Tommasini (2004). Other isolated predators and pestiferous insect species were identified by reference to material in the Entomology Laboratory of the Plant Protection Department, Faculty of Agriculture, University of Çukurova, Adana, Turkey. No identification keys are available for nymphs of Orius. Therefore, these were treated as a single entity.

\subsection{Data analysis}

Surveys of thrips and predatory insects were performed only in commercial fields in the 2014-2015, and 2016-2017 growing seasons (Tables 1,2). The populations of other pest insects including aphids and leaf hoppers and some predators were not quantified because their numbers were small throughout the sampling period. Larval thrips were not evaluated due to their low numbers on faba bean plants sampled in all locations. Effects of plant parts and sampling dates on the abundance of Orius spp. adults (pooled) and nymphs (pooled) and $F$. occidentalis adults were evaluated by using General Linear Model (GLM) repeated measures statistical analysis (Groves et al., 2003). Weekly comparisons of the numbers of thrips and Orius on leaflets and flowers were made throughout the sampling period by using Student's t-test at $P<0.05$. Numbers of $F$. occidentalis and Orius spp. per plant part (leaflets and flowers) were pooled over sampling dates and sampling years. Their mean numbers were grouped by Student's t-test at $P<0.05$.

The relationship of mean numbers of thrips and Orius in the flowers was evaluated by using quadratic regression analysis at $P<0.05$ significance level. The relationship between climatic factors (mainly average temperature and relative humidity) and thrips or Orius populations in all fields was analysed using SPSS 15.0. (SPSS, 2006).

\section{Results and Discussion}

\subsection{Surveyed thrips and predatory insect species in 2014-15 and 2016-17}

Ten species of thrips were identified during the 2014-2015, and 2016-2017 growing seasons (Table 1). All major species belonged to the family Thripidae, where as representatives of Aeolothripidae were found in fewer numbers. F. occidentalis (Pergande), Thrips tabaci Lindeman, and Thrips hawaiiensis (Morgan) were the most common species. F. occidentalis was the dominant species in the thrips fauna. It was represented in $44.0 \%$ of the total samples and accounted for $89.5 \%$ of all specimens.

Table 1 Composition, distribution, and abundance of thrips species on faba beans grown commercially in Adana Province, Turkey, 2014-2015, and 2016-2017

\begin{tabular}{|c|c|c|c|c|c|c|c|c|}
\hline \multirow{2}{*}{ Family and species } & \multicolumn{2}{|c|}{ Frequency per year } & \multicolumn{2}{|c|}{ Abundance per year } & \multicolumn{2}{|c|}{ Overall frequency } & \multicolumn{2}{|c|}{ Overall abundance } \\
\hline & 2014-15 & 2016-17 & $2014-15$ & 2016-17 & Number & $\%$ & Number & $\%$ \\
\hline \multicolumn{9}{|c|}{ Aeolothripidae } \\
\hline Aeolothrips collaris & 0 & 1 & 0 & 1 & 1 & 0.21 & 1 & 0.16 \\
\hline Melanthrips fuscus & 1 & 1 & 1 & 1 & 2 & 0.42 & 2 & 0.33 \\
\hline Melanthrips pallidor & 1 & 1 & 1 & 1 & 2 & 0.42 & 2 & 0.33 \\
\hline \multicolumn{9}{|c|}{ Thripidae } \\
\hline Frankliniella occidentalis & 77 & 130 & 193 & 350 & 207 & 44.04 & 543 & 89.46 \\
\hline $\begin{array}{l}\text { Isoneuro thrips } \\
\text { avustralis }\end{array}$ & 1 & 0 & 1 & 0 & 1 & 0.21 & 1 & 0.16 \\
\hline Kakothrips priesneri & 1 & 0 & 1 & 0 & 1 & 0.21 & 1 & 0.16 \\
\hline Thrips hawaiiensis & 0 & 14 & 0 & 24 & 14 & 2.9 & 24 & 3.96 \\
\hline Thrips meridonalis & 0 & 3 & 0 & 3 & 3 & 0.63 & 3 & 0.50 \\
\hline Thrips major & 0 & 1 & 0 & 1 & 1 & 0.21 & 1 & 0.16 \\
\hline Thrips tabaci & 15 & 2 & 27 & 2 & 17 & 3.61 & 29 & 4.78 \\
\hline
\end{tabular}

Journal of Experimental Biology and Agricultural Sciences http://www.jebas.org 
Table 2 Composition, distribution, and abundance of bene ficial insects on faba beans grown commercially in Adana Province, Turkey, 2014-2015, and 2016-2017

\begin{tabular}{|c|c|c|c|c|c|c|c|c|}
\hline \multirow{2}{*}{ Family and species } & \multicolumn{2}{|c|}{ Frequency per year } & \multicolumn{2}{|c|}{ Abundance per year } & \multicolumn{2}{|c|}{ Overall frequency } & \multicolumn{2}{|c|}{ Overall abundance } \\
\hline & 2014-15 & 2016-17 & 2014-15 & 2016-17 & Number & $\%$ & Number & $\%$ \\
\hline \multicolumn{9}{|c|}{ Cole./Cocciellidae } \\
\hline Adonia variegata & 0 & 2 & 0 & 2 & 2 & 0.42 & 2 & 0.62 \\
\hline Coccinella septempunctata & 2 & 2 & 2 & 2 & 4 & 0.85 & 4 & 1.25 \\
\hline \multicolumn{9}{|c|}{ Cole./Staphylinidae } \\
\hline Paederus sp. & 0 & 1 & 0 & 1 & 1 & 0.21 & 1 & 0.31 \\
\hline Tachyporus & 3 & 1 & 3 & 1 & 4 & 0.85 & 4 & 1.25 \\
\hline \multicolumn{9}{|c|}{ Hem./ Anthocoridae } \\
\hline Orius laevigatus & 7 & 11 & 7 & 11 & 18 & 3.82 & 18 & 5.60 \\
\hline Orius majusculus & 3 & 3 & 3 & 3 & 6 & 1.27 & 6 & 1.86 \\
\hline Orius niger & 103 & 52 & 172 & 76 & 155 & 32.97 & 248 & 77.27 \\
\hline Orius vicinus & 0 & 1 & 0 & 1 & 1 & 0.21 & 1 & 0.31 \\
\hline \multicolumn{9}{|c|}{ Hem. /Lygaeidae } \\
\hline Piocoris erythrocephalus & 0 & 1 & 0 & 1 & 1 & 0.21 & 1 & 0.31 \\
\hline \multicolumn{9}{|c|}{ Hem./Miridae } \\
\hline Campylomma nicolasi & 15 & 13 & 15 & 17 & 28 & 5.95 & 32 & 9.97 \\
\hline \multicolumn{9}{|c|}{ Neu./Chrysopidae } \\
\hline Chrysoperla carnea & 0 & 4 & 0 & 4 & 4 & 0.85 & 4 & 1.25 \\
\hline
\end{tabular}

Thrips tabaci ranked second with representation in $36.0 \%$ of the total samples and accounting for $4.8 \%$ of adult specimens collected. The other species was found in $0.2-2.9 \%$ of the total sample and represented $0.2-0.3 \%$ of the total specimens (Table 1 ). $F$. occidentalis was the most active thrips species, and appeared on several crops and weeds throughout the winter season. These results agree with those of Atakan \& Uygur (2005), who reported high populations of $F$. occidentalis in the winter. The dominance of $F$. occidentalis on winter crops might be due to its higher reproductive rate, large numbers of its host plants, and its better adaptation to hard winter conditions worldwide (Kirk \& Terry 2003).

Other pest insects, such as Empoasca decipiens Paoli (Hemiptera: Cicadellidae), Aphis fabaea Scop. and Acyrthosiphon pisum (Harris) (Hemiptera: Aphididae), and Nezara viridula L. (Hemiptera: Pentatomidae), were also collected during the study period but their numbers were small and were not evaluated. However, in previous work by Atakan (2012), Atakan (2016) in the same area, the presence of other pest insects was also reported on faba bean.

Eleven predatory insect species in the orders Coleoptera (two coccinellids and two staphylinids), Hemiptera (four anthocorids, one mirid, and one lygaeid), and Neuroptera (one chrysopid) were identified (Table 2). Orius niger (Wolff), Campylomma nicolasi Puton and Reuter, and Orius laevigatus (Fieber) were the most notable predators. $O$. niger was dominant, being present in $32.9 \%$ of samples and accounting for $77.2 \%$ of adult specimens. The results agree with those of Tommasini (2004), who reported that O. niger, O. laevigatus, and O. majusculus (Reuter) were common anthocorid species in the Mediterranean basin. O. niger was dominant in north western Italy, whereas O. laevigatus was more common in the warmest locations of the country (Bosco et al., 2008). Thus, the predominance of insect species may depend on location. C. nicolasi was the second most common predator, being represented in 5.9\% of the samples and accounting for about $9.9 \%$ of the specimens (Table 2). Overall frequency and abundance of 
the other predatory insect species varied from 0.2 to $3.8 \%$ and 0.3 to $5.6 \%$, respectively (Table 2). A few coccinellid beetles (Coleoptera) were also detected. Low numbers of coccinellids paralleled the low numbers of their prey, such as aphids, in all fields surveyed. C. undecimpunctata and $C$. septempunctata were more abundant in Egyptian broad bean fields and had a consistent relationship with their prey, Aphis craccivora Koch (Gameel, 2014). Similarly, A. craccivorais a serious pest of faba beans in Egypt (Aly, 2014).

Total numbers of thrips and predatory insect species on faba beans in commercial fields were low compared with numbers in the experimental field (Tables 1,2). This result might be because of excessive application of pesticides against common pests and diseases of faba bean. In previous work (Atakan, 2012; Atakan, 2016), the populations of leafhoppers, aphids, and predatory anthocorids on faba bean were higher in the experimental plots in which no pesticide was used.
3.2. Distribution of $F$. occidentalis and O.niger on various plant parts in 2010 and 2011

Distribution of $F$. occidentalis and $O$. niger on various plant parts was studied only in experimental plots in years 2010 and 2011. Sampling date and sampling date $\times$ plant part interaction have significant effects on abundance of thrips and Orius spp. (Table 3). The majority of thrips and adults and nymphs of Orius spp. were found on the flowers of faba bean (Figure 1). Cumulative mean numbers of thrips and Orius were significantly higher on flowers than on leaves in 2015 ( $F$. occidentalis: $t=4.799, F_{1,38}=$ 23.027, $P<0.0001$; adult Orius spp.: $t=4.551, F_{1,38}=29.710$, $P<0.0001$; nymphs of Orius spp.: $t=3.672, F_{1,38}=13.486 .400, P<$ 0.0001 ) and in 2016 (F. occidentalis: $t=3.426, F_{1,38}=11.740$, $P<0.001$; adult Orius spp.: $t=7.085, F_{1,38}=50.203, P<0.0001$; nymphs of Orius spp: $t=2.530, F_{1,38}=6.400, P=0.016$ ) (Figure 2).

When prey for Orius species is not available, they can feed on nectar and pollen; consequently, their populations are higher on

Table 3 Results of repeated measures statistical analysis (RM-ANOVA)

\begin{tabular}{|c|c|c|c|c|}
\hline Source & Df & MS & $\mathrm{F}$ & Significance \\
\hline \multicolumn{5}{|c|}{ Thrips (Within subject effects) } \\
\hline Date & 8 & 1.019 & 7.427 & $P<0.0001$ \\
\hline Date $\times$ plantpart & 8 & 0.519 & 3.782 & $P<0.0001$ \\
\hline Error & 304 & & & \\
\hline \multicolumn{5}{|c|}{ Between subject effects } \\
\hline Intercept & 1 & 12.100 & 65.686 & $P<0.0001$ \\
\hline Plantpart & 1 & 4.900 & 26.600 & $P<0.0001$ \\
\hline \multicolumn{5}{|l|}{ Error } \\
\hline \multicolumn{5}{|c|}{ Orius spp. (Within subject effects) } \\
\hline Date & 11 & 0.425 & 3.214 & $P<0.0001$ \\
\hline Date $\times$ plantpart & 11 & 0.469 & 3.546 & $P<0.0001$ \\
\hline Error & 418 & & & \\
\hline \multicolumn{5}{|c|}{ Between subject effects } \\
\hline Intercept & 1 & 6.302 & 44.382 & $P<0.0001$ \\
\hline Plantingdate & 1 & 4.219 & 29.710 & $P<0.0001$ \\
\hline Error & 38 & & & \\
\hline
\end{tabular}




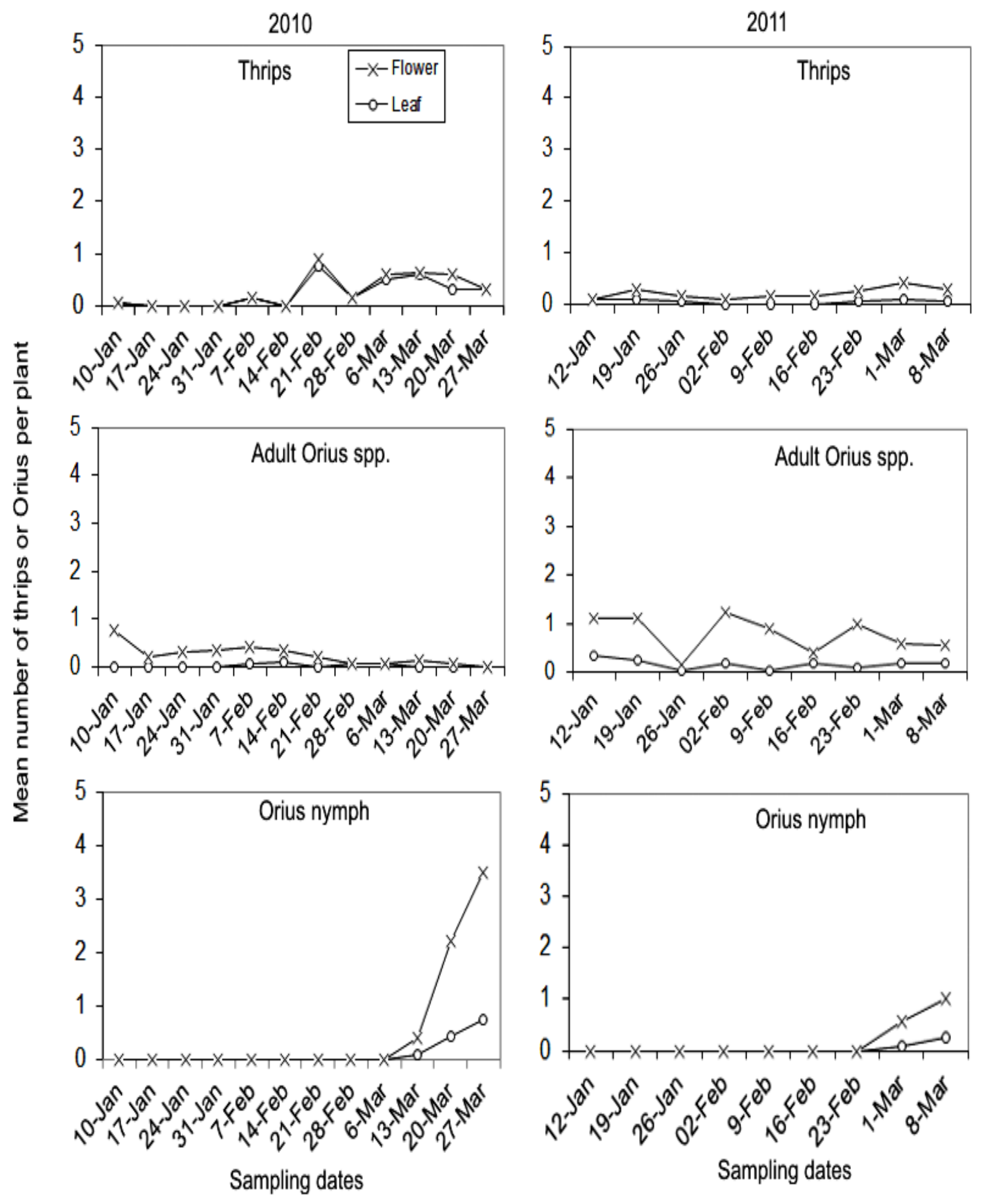

Figure 1 Mean numbers of $F$. occidentalis and Orius spp. on two plant parts of faba beans in experimental plots in Adana province, Turkey, 2010 and 2011

Journal of Experimental Biology and Agricultural Sciences http://www.jebas.org 

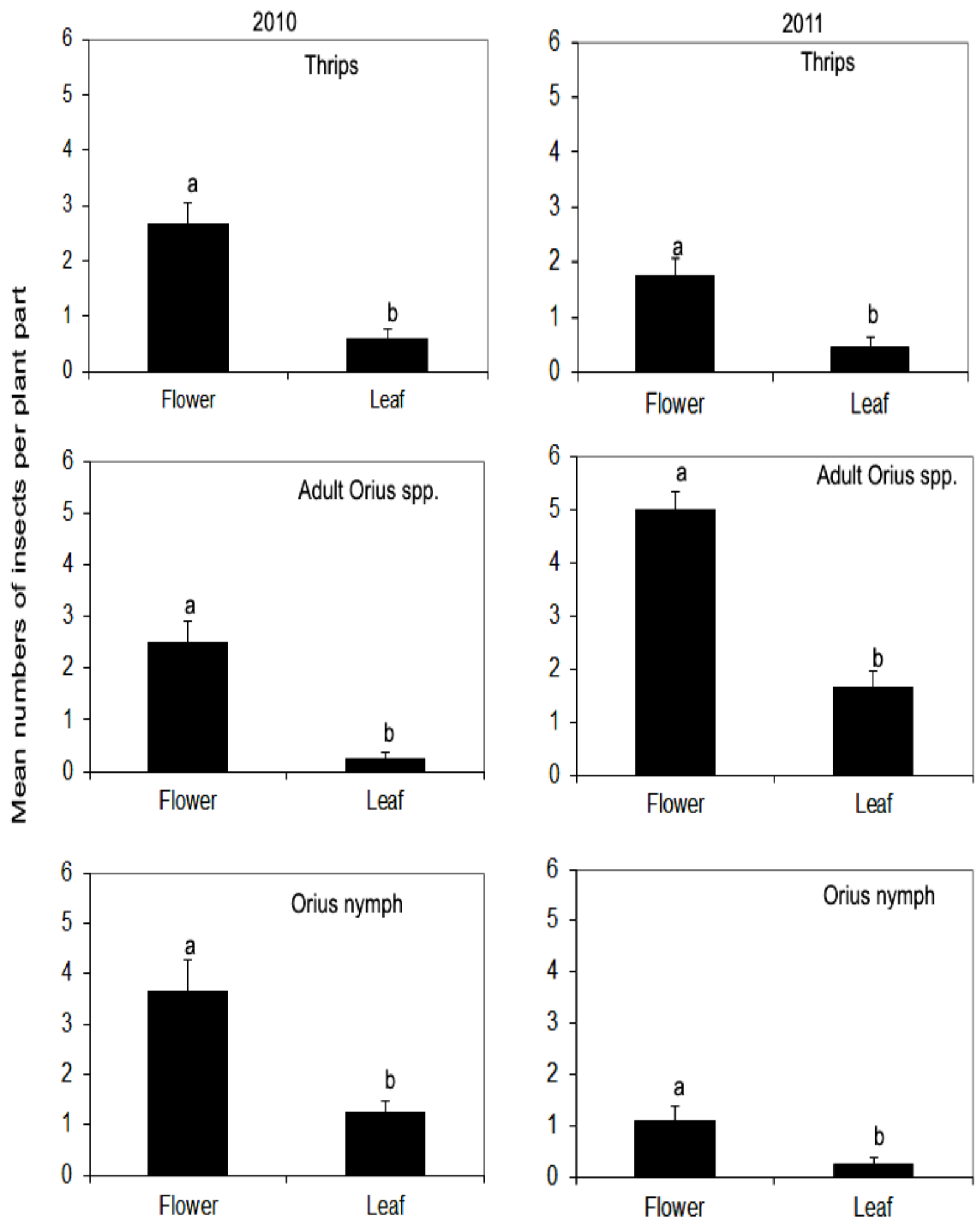

Figure 2 Cumulative mean numbers of $F$. occidentalis and Orius spp. On two plant parts of faba beans in experimental plots in Adana province, Turkey, 2010 and 2011 

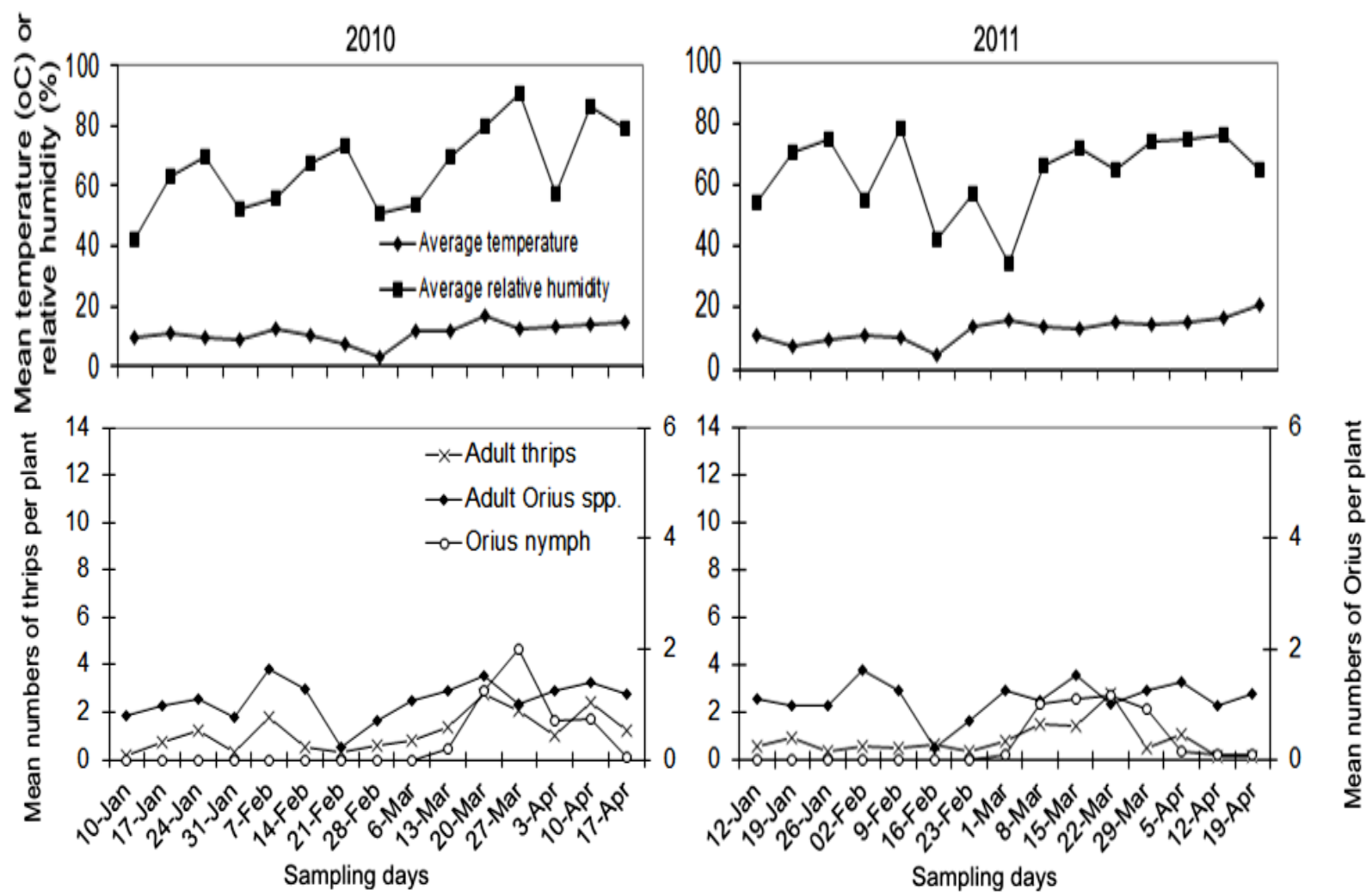

Figure 3 Mean numbers of F. occidentalis and Orius spp. on faba beans of experimental plot in Adana province, Turkey, 2010 and 2011.

flower parts (Kiman \& Yeargan, 1985; Riudavets, 1995). Faba bean might be a source of extra-floral nectar, which supports Orius spp. regardless of the presence of $F$. occidentalis or other prey. Many beneficial insects were detected in faba beans cultivated in southern Florida (USA) (Nuessly et al., 2004). The densities of the bean's flowers might have affected the densities of Orius spp. more than their prey (thrips). An abundance of Orius adults in the experimental areas might support this suggestion (Atakan, 2010).

\subsection{Abundances of thrips and Orius on flowers}

\subsubsection{Years 2010 and 2011}

Mean numbers of thrips were highest in flowers. The numbers began increasing after 21 February 2010 (0.55 thrips per plant) and reached a maximum on 13 March 2010; thereafter, numbers started decreasing (Figure 3). When thrips populations were highest on plants, the mean temperature was relatively low (7.3 ${ }^{\circ} \mathrm{C}$ ) and relative humidity was $73.7 \%$. No thrips were found in April when few flowers were detected on the plants. Numbers of Orius were higher, with means of 2.0-3.5 individuals per plant in January to mid-April when thrips numbers were high, but there was no correlation between thrips and Orius spp. numbers. The population of Orius spp. was highest in flowers on 27 March, as was thrips density. The first nymphs of Orius spp. appeared on 13 March (mean of 0.2 Orius individuals per plant). Two weeks later, the mean density of Orius nymphs was the highest (mean of 1.2 individuals per plant).

The results for 2011 are similar to those of 2010; the mean number of thrips ranged from 0.3 to 0.9 in January-February (Figure 3). Thereafter, the density of thrips started to increase and peaked in flowers, with a mean density of 2.8 thrips per plant on 22 March 2011; the thrips population then declined. When the thrips population was greatest, the mean temperature was relatively high $\left(14.4^{\circ} \mathrm{C}\right)$, and there was no apparent increase in relative humidity on this date. The mean numbers of adult Orius spp. were similar throughout the sampling period and varied between 2 and 3 individuals per plant. The first nymphs of Orius spp. were detected on 1 March. During March, mean densities of Orius nymphs remained constant, with an average of one individual per plant. In April, variation in mean numbers of Orius nymph was recorded and the pattern of nymphal occurrence showed similarities with the adult population of thrips and Orius. 


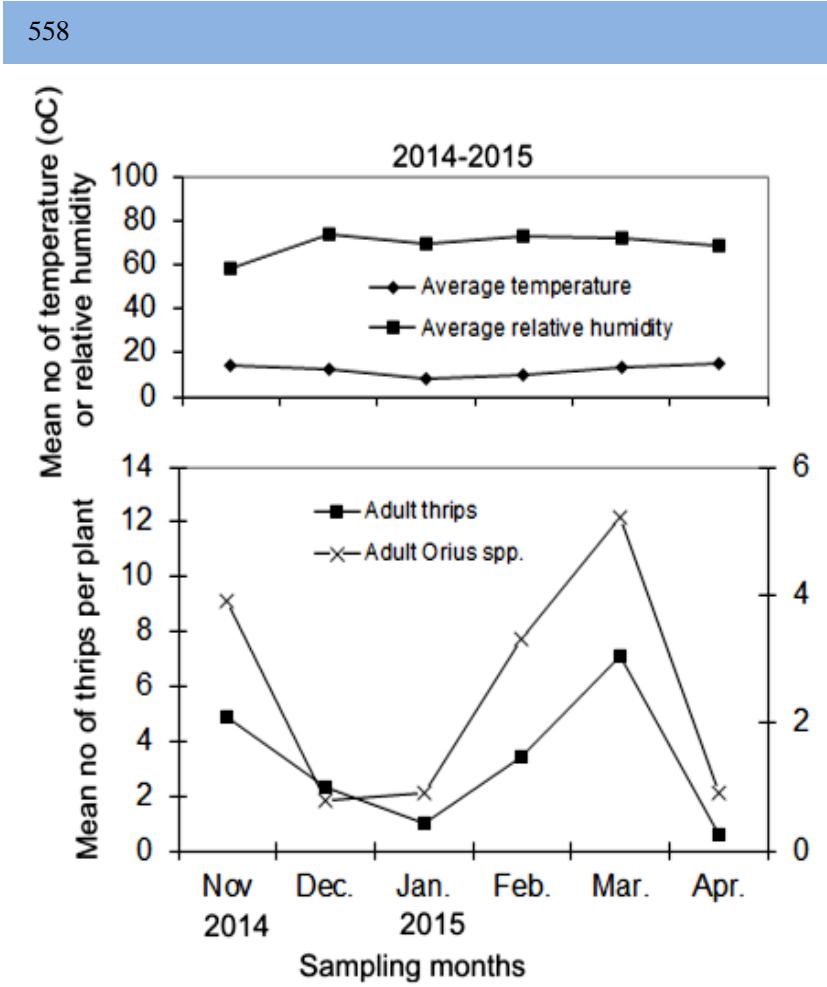

Figure 4 Monthly mean numbers of F.occidentalis and Orius spp. on faba beans grown commercially in Adana province, Turkey, 2014-2015, and 2016-2017

\subsubsection{Season 2014-15}

In the 2014-2015 growing season, the monthly mean densities of thrips and Orius spp. in flowers are shown in Figure 4. The mean density of $F$. occidentalis was 4.9 individuals per plant in November 2014; thereafter, the thrips population declined until February 2015 and then peaked in March (7.1 individuals per plant). The mean density of thrips decreased to its lowest level in April (0.6 individuals per plant). Low temperature in March (13.3 ${ }^{\circ} \mathrm{C}$ ) favoured the development of thrips populations. Increases in temperature negatively affected the multiplication of thrips in flowers, possibly explaining the reduced thrips population in April. The Orius population followed the thrips population in flowers in the 2014-2015 growing season. The number of Orius (5.2 individuals per plant) cope with the thrips population in 2014-2015.

\subsubsection{Season 2016-17}

Monthly mean densities of thrips were greater in the 2016-2017 growing season (Figure 4) than in the previous study year. Thrips densities were high from December (10.6 individuals per plant) to March (11.9 individuals per plant) and the effect of temperature was more pronounced. The density of thrips was lowest in October (mean number of 0.8 individuals per plant). Mean
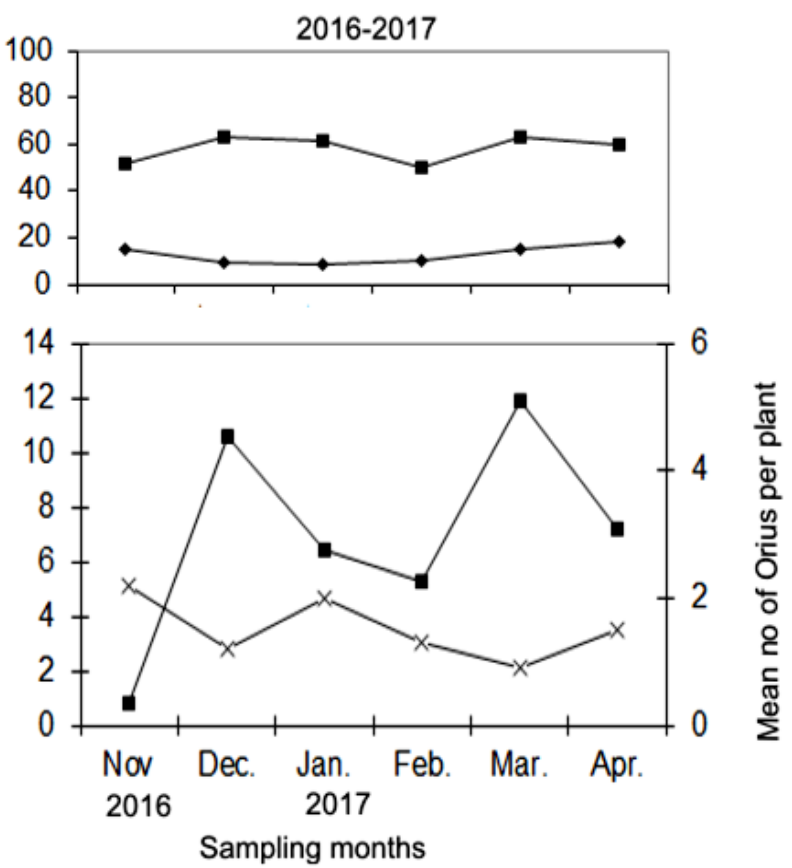

densities of Orius spp. were lower than those of thrips throughout the sampling period, ranging from 0.9 to 2.2 individuals per plant.

Increasing temperature in March favoured the development of thrips densities but further increases in temperature (in April) negatively influenced thrips abundance, which began decreasing in the first week of April. Like temperature, low flower density of faba bean also affects thrips abundance; it was higher until March but began decreasing in April. There was no correlation between mean densities of thrips or Orius spp. and mean temperature or relative humidity in any year. However, increasing temperature might have positively influenced egg-hatching of Orius. Hence, the first nymphs of Orius spp. were detected in early March. Orius numbers were also less during non-flowering periods.

Orius might be a regulating factor of thrips dynamics on faba bean plants. A previous study in the same ecological area, suggested a positive relationship between the densities of $F$. occidentalis and O. niger in faba bean flowers (Atakan, 2010). Faba bean plants might be a good trap crop for thrips and a banker plant for beneficial insects, such as predatory bugs (Orius spp.). The findings of Smith et al. (2013) are contradictory to those of the present study. These researchers suggested that faba bean is not a good trap crop for thrips in the Snow Peas region of Guatemala. The differences might be attributable to ecological 

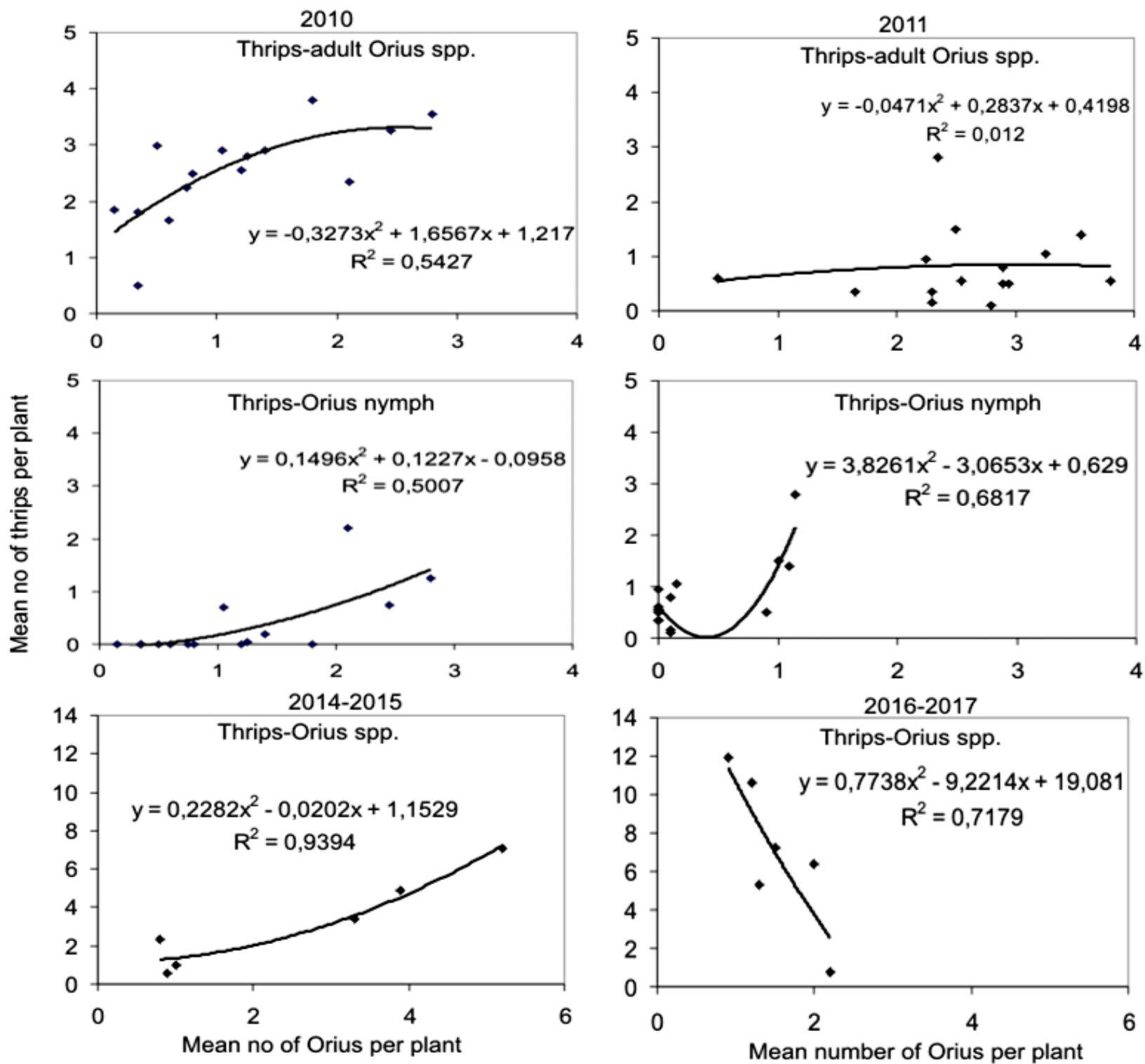

Figure 5 Relationships between adult thrips and adult Orius, and adult thrips and Orius nymphs on faba beans in Adana province, Turkey, 2010 and 2011, 2014-2015 and 2016-2017

differences between the geographical regions. F. occidentalis numbers were relatively higher in commercial fields (Figure 4) when compared with those of the previous growing season (Figure 3). This difference might be due to pesticide applications in commercial fields. However, the Orius population on faba beans in commercial fields followed the population of thrips.

\subsection{Thrips-predator relationships}

In experimental plots, the mean abundance of $O$. niger in faba bean flowers was significantly higher compared with that of thrips in 2010 and 2011. In 2010, there was a significant and positive relationship between thrips and adults of Orius spp. $\left(F_{1,13}=6.081\right.$, $P=0.015)$ and thrips and Orius nymphs $\left(F_{1,13}=7.7201, P=\right.$ 0.009) (Figure 5). In 2011, the thrips population did not follow the pattern of the adult Orius population. A significant and positive relationship between numbers of thrips and nymphs of Orius was detected $\left(F_{1,13}=12.851, P=0.001\right)$ (Figure 5). There was a consistent relationship between numbers of thrips and Orius spp. in the 2014-2015 $\left(F_{1,4}=14.389 P=0.02\right)$ and 2016-2017 growing seasons $\left(F_{1,4}=6.837, P=0.036\right)$ (Figure 5). The low abundance of $F$. occidentalis throughout the autumn-spring period on faba bean 
Table 4 Total numbers of thrips and Orius and prey:predator ratios on faba beans in Adana Province, Turkey, 2010-2011, 2014-2015, and 2016-2017

\begin{tabular}{|c|c|c|c|c|}
\hline $\begin{array}{l}\text { Sampling } \\
\text { year or } \\
\text { period }\end{array}$ & Months & $\begin{array}{l}\text { No. of } \\
\text { Thrips }\end{array}$ & $\begin{array}{c}\text { No. of } \\
\text { Orius }\end{array}$ & $\begin{array}{c}\text { Prey } \\
\text { (thrips):predator } \\
\text { (Orius) ratios }\end{array}$ \\
\hline \multirow[t]{5}{*}{2010} & January & 8 & 140 & 0.05 \\
\hline & February & 54 & 221 & 0.44 \\
\hline & March & 90 & 233 & 0.38 \\
\hline & April & 7 & 70 & 0.10 \\
\hline & Total & 159 & 664 & \\
\hline \multirow[t]{5}{*}{2011} & January & 40 & 179 & 0.23 \\
\hline & February & 40 & 178 & 0.22 \\
\hline & March & 140 & 284 & 0.49 \\
\hline & April & 26 & 167 & 0.15 \\
\hline & Total & 246 & 808 & \\
\hline \multirow[t]{6}{*}{ 2014-2015 } & November & 49 & 70 & 0.70 \\
\hline & December & 23 & 8 & 2.87 \\
\hline & January & 10 & 12 & 0.83 \\
\hline & February & 34 & 33 & 1.03 \\
\hline & March & 71 & 52 & 1.36 \\
\hline & April & 6 & 9 & 0.66 \\
\hline \multirow[t]{7}{*}{ 2016-2017 } & November & 8 & 22 & 0.66 \\
\hline & December & 106 & 12 & 4.81 \\
\hline & January & 64 & 20 & 3.20 \\
\hline & February & 53 & 13 & 4.07 \\
\hline & March & 119 & 9 & 13.2 \\
\hline & April & 72 & 15 & 4.8 \\
\hline & Total & 615 & 275 & \\
\hline
\end{tabular}

Table 5 Prey:predator ratios on two plant parts of faba beans in Adana Province, Turkey, 2010-2011

\begin{tabular}{|lccllll|}
\hline & \multicolumn{3}{c}{ Leaves } & \multicolumn{3}{c|}{ Flowers } \\
Months & $\begin{array}{l}\text { No. } \\
\text { of } \\
\text { thrips }\end{array}$ & $\begin{array}{l}\text { No. of } \\
\text { Orius }\end{array}$ & $\begin{array}{l}\text { Prey (thrips) } \\
\text { : predator } \\
\text { (Orius) } \\
\text { ratios }\end{array}$ & $\begin{array}{l}\text { No. } \\
\text { of } \\
\text { thrips }\end{array}$ & $\begin{array}{l}\text { Orius } \\
\text { Year 2010 }\end{array}$ & $\begin{array}{l}\text { Prey } \\
\text { (thrips): } \\
\text { predator } \\
\text { (Orius) } \\
\text { ratios }\end{array}$ \\
\hline January & 0 & 0 & - & 0 & 25 & - \\
\hline February & 3 & 3 & 3 & 18 & 22 & 0.81 \\
\hline March & 9 & 1 & 9 & 36 & 73 & 0.49 \\
\hline April & 0 & 0 & - & 7 & 30 & 0.23 \\
\hline Total & 12 & 4 & & 61 & 150 & \\
\hline & & & Year 2011 & & & \\
\hline January & 6 & 13 & 0.46 & 6 & 34 & 0.17 \\
\hline February & 1 & 11 & 0.09 & 12 & 56 & 0,21 \\
\hline March & 3 & 8 & 0.37 & 11 & 15 & 0.73 \\
\hline Total & 10 & 32 & & 29 & 105 & \\
\hline
\end{tabular}

Journal of Experimental Biology and Agricultural Sciences http://www.jebas.org might have resulted from thrips population suppression by predatory bugs. The results also revealed that larval thrips had a higher risk of predation than did the adults.

\subsection{Prey (thrips)-predator (Orius) ratio on flowers}

The prey-predator ratio was less than 0.5 thrips per Orius in the experimental plots in 2010 and 2011 (Table 4). In commercial fields during the 2014-2015 growing season, the lowest prey-predator ratio ( 0.7 thrips per Orius) was in April, while the highest prey-predator ratio (2.9 thrips per Orius) was in December (Table 4). In 2016-2017, prey-predator ratios were higher compared with 20142015. During this growing season, the thrips: Orius ratio ranged between 0.7 and 13.2. Thrips suffered more due to Orius spp. attacks in November (0.7 thrips per Orius spp.) and less in March (13.2 thrips per Orius spp.).

\subsection{Prey (thrips)-predator (Orius) ratio on various plant parts}

Prey (thrips)-predator (Orius) ratios on various plant parts i.e. leaflets and flowers of faba bean were also studied in only experimental plots in years 2010 and 2011 (Table 5). In 2010, the lowest numbers of thrips and Orius were recorded on faba bean leaves (Table 5). In January and April, no thrips were found on leaves of faba bean. For flowers also, a reduction in the prey:predator ratios was reported after January 2010 and 2011. In both years, prey-predator ratios in flowers were less than one thrips per Orius, indicating that thrips might have a higher predation risk in flowers rather than on leaves (Table 5). Delayed suppression of thrips populations was assumed for anthocorid-thrips ratios greater than 1:217, where as immediate suppression of populations was observed within 6.5 days at predatorprey ratios greater than 1:50 (van den Meiracker \& Ramakers, 1991).

In the present study, the ratio of prey to predator in flowers ranged from 0.05 to 13.2 and was below five adult thrips per Orius on most sampling months. Funderburk et al. (2000) concluded that numbers of $F$. occidentalis colonizing field peppers were near zero within days after predator : prey ratios reached 1:40. The present results suggest that thrips on faba bean plants might have suffered most from predation by Orius spp. because prey-predator ratios were often lower than the ratios in previous studies. 


\section{Conclusion}

Although faba bean hosted many pest species, their numbers were low and their damage to plants was not observed. Orius species were the most common predaceous insects in the faba bean fields. Flower densities on plants might be a primary factor for the presence and abundance of Orius spp., rather than their insect prey, such as thrips. Cultivation of faba bean in October seems to be a good cultural practice because (i) plants have relatively high densities of predators (mainly Orius spp.) and relatively low numbers of pest thrips and other pest insects, and (ii) plants generate more green pods. Growing of faba bean in the winterspring period, especially in agricultural areas having poor plant diversity in the Mediterranean region, could be useful for conservation and augmentation of beneficial insects.

\section{Acknowledgements}

I would like to extend my thanks to Prof. Dr. Peter ADLER (Clemson University, south Carolina, USA) and to Prof. Dr. M. Bora KAYDAN (Vocational School of İmamoğlu, University of Çukurova, Adana, Turkey) for reviewing of the manuscript.

\section{Conflict of Interest}

The author declares that there were no conflicts of interest.

\section{References}

Aly AA (2014) Toxicity and persistence of selected neonicotinoid insecticides on cowpea aphid, Aphis craccivora Koch (Homoptera: Aphididae). Archives of Phytopathology and Plant Protection 3:366-376.

Anonymous (2001) $8^{\text {th }}$ Plan of the Improvement of Turkey Economy for Five Years: Plant Production. Report of SubCommission of Cereals and Leguminous, DPT: 2644-ÖİK: 652. Ankara, Turkey, P. 146. (in Turkish)

Atakan E (2006) Associations between Frankliniella spp. and Orius niger populations in cotton. Phytoparasitica 34:221-234.

Atakan E (2010) Influence of weedy field margins on abundance patterns of the predatory bugs Orius spp. and their prey, the western flower thrips (Frankliniella occidentalis), on faba bean. Phytoparasitica 38:313-325.

Atakan E (2012) Abundance patterns of predatory bugs, Orius spp. (Hemiptera: Anthocoridae) and their some insect preys on faba bean with different planting dates in Adana province, Turkey. Türkiye Entomooji Bülteni 2:37-48.

Atakan E (2016) Insect species and their densities on faba bean (Vicia faba L.) grown in two diverse habitats. Türkiye Biyolojik Mücadele Dergisi 7:31-42.
Atakan E, Uygur S (2005) Winter and spring abundance of Frankliniella spp. and Thrips tabaci Lindeman (Thysan., Thripidae) on weed host plants in Turkey. Journal of Applied Entomology 129:17-26

Atakan E, Gençer O (2008) Influence of planting date on the relationship between populations of Frankliniella flower thrips and predatory bug Orius niger in cotton. Journal of Pest Science 81:123-133.

Balou MM, Tong XL, Chen XX (2012) A new record and description of a new species of the genus thrips with an updated key to species from Iran. Journal of Insect Science 12:1-15.

Bosco L, Giacometto E, Tavella L (2008) Colonization and predation of thrips (Thysanoptera: Thripidae) by Orius spp. (Heteroptera: Anthocoridae) in sweet pepper greenhouses in Northwest Italy. Biocontrol 44:331-340.

Bulut E, Göçmen H (2000) Pests and their natural enemies on greenhouse vegetables in Antalya. IOBC/ WPRS Bulletin 23:3337.

Funderburk J, Stavisky J, Olson S (2000) Predation of Frankliniella occidentalis (Thysanoptera: Thripidae) in field peppers by Orius insidiosus (Hemiptera: Anthocoridae). Environmental Entomology 29:376-382.

Gameel SMM (2014) Effect of planting date on seasonal abundance of the Aphis craccivora Koch and associated predators in the new Valley-Egypt. Egyptian. Academic Journal of Biological Science 7:97-103.

Groves RL, Walgenbach JF, Moyer JW, Kennedy GG (2003) Seasonal dispersal patterns of Frankliniella fusca (Thysanoptera: Thripidae) and tomato spotted wilt virus occurrence in central and eastern North Carolina. Journal Economic Entomology 96: 1-11.

Kiman ZB, Yeargan KV (1985) Development and reproduction of the predator Orius insidiosus (Hemiptera: Anthocoridae) reared on diets of selected plant material and arthropod prey. Annals of Entomology Society of America 78:464-467.

Kirk WDJ, Terry LI (2003) The spread of the western flower thrips, Frankliniella occidentalis (Pergande). Agriculture and Forestry Entomology 5:301-310.

Nuessly GS, Hentz MG, Beiriger R, Scully BT (2004) Insects associated with faba bean, Vicia faba (Fabales: Fabaceae), in southern Florida. Florida Entomologist 87:204-211.

Önder F (1982) Contribution to the Study of Turkish Anthocoridae (Heteroptera). Ege Üniversitesi Ziraat Fakültesi 
Ofset Basımevi, Bornova-İzmir, Turkey, pp.159 (In Turkish with English abstract).

Razavi N, Ahmadi K (2016) Compatibility assessment between four ethanolic plant extracts with a bug predator Orius horvathi (Reuter) (Heteroptera: Anthocoridae) used for controlling the western flower thrips Frankliniella occidentalis (Pergande) (Thysanoptera: Thripidae). Journal of Plant Protection Research 56:89-94.

Riudavets J (1995) Predators of Frankliniella occidentalis (Perg.) and Thrips tabaci L ind.: a review. In: Loomans AJM, Van Lenteren JC, Tommasini MG, Maini S, Riudavets J (Eds.), Biological Control of Thrips Pests Wageningen Agricultural University Papers, 95.I, Wageningen, Pp. 20.

Smith HA, Macvean CM, Bailey AC, Benavente JM (2013) Faba beans are not a good trap crop for thrips (Thysanoptera: Thripidae) in snow peas in Guatemala. Florida Entomologist 94:1603-1605.

SPSS (2006). SPSS base 15.0 user's guide. Chicago, IL, USA: Prentice Hall.
Tavella L, Tedeschi R, Arzone A, Alma A (2000) Predatory activity of two Orius species on the western flower thrips in protected pepper crops (Ligurian Riviera, Italy). IOBC/WPRS Bulletin 23:231-240.

Tommasini MG (2004) Collection of Orius species in Italy. Bulletin of Insectology 57:65-72.

Van den Meiracker RAF, Ramakers PMJ (1991) Biological control of the western flower thrips, Frankliniella occidentalis on sweet pepper with the anthocorid predator Orius insidiosus. Meded Fakulteit Landbouw wet. Rijks University Gent 56 : 241-249.

van de Veire M, Degheele D (1992) Biological control of the western flower thrips Frankliniella occidentalis (Pergande) (Thysanoptera: Thripidae), in glasshouse sweet peppers with Orius spp. (Hemiptera: Anthocoridae): a comparative study between $O$. niger (Wolff) and $O$. insidiosus (Say). Biocontrol Science and Technology 2:281-283.

zur Strassen R(2003) Die Terebranten Thysanopteren Europas. Verlag Goecke and Evers, Kentern, Germany Pp. 277 (in Germany) 